\title{
Frugivory and seed dispersal of golden lion tamarin (Leontopithecus rosalia (Linnaeus, 1766)) in a forest fragment in the Atlantic Forest, Brazil
}

\author{
Lapenta, MJ. ${ }^{\mathrm{a}, \mathrm{b} *}$, Procópio-de-Oliveira, P. $^{\mathrm{b}}$, Kierulff, MCM. ${ }^{\mathrm{b}}$ and Motta-Junior, JC. ${ }^{\mathrm{a}}$

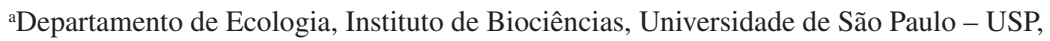 \\ Rua do Matão 321, Trav. 14, CEP 05508-90, Butantã, São Paulo, SP, Brazil \\ ${ }^{\mathrm{b}}$ Programa de Translocação, Associação Mico-Leão-Dourado, \\ CP 109.995, CEP 28860-000, Casimiro de Abreu, RJ, Brazil \\ * e-mail: mjlapenta@yahoo.com.br
}

Instituto Pri-Matas para a Conservação da Biodiversidade CP 3304, CEP 30140-970, Belo Horizonte, MG, Brazil

Received March 27, 2006 - Accepted August 17, 2006 - Distributed May 31, 2008

\begin{abstract}
The influence of the golden lion tamarin (Leontopithecus rosalia) as a seed disperser was studied by monitoring two groups of tamarins from December 1998 to December 2000 (871.9 hours of observations) in a forest fragment in southeast Brazil. The tamarins consumed fruits of 57 species from at least 17 families. They ingested the seeds of 39 species, and 23 of these were put to germinate in the laboratory and/or in the field. L. rosalia is a legitimate seed disperser because the seeds of all species tested germinated after ingestion, albeit some in low percentages. These primates do not show a consistent effect in final seed germination, because they benefit some species while damaging others. Feces were examined for seeds that had been preyed upon or digested.
\end{abstract}

Keywords: Atlantic Forest, golden lion tamarin, Leontopithecus rosalia, seed dispersal, seed germination.

\section{Frugivoria e dispersão de sementes por Micos-Leões-Dourados (Leontopithecus rosalia) em um fragmento florestal na Mata Atlântica, Brasil}

\begin{abstract}
Resumo
A influência do mico-leão-dourado (Leontopithecus rosalia) como dispersor de sementes foi estudada através do monitoramento de dois grupos de micos de dezembro de 1998 a dezembro de 2000 ( 871,9 horas de observações) em um fragmento florestal no Sudeste do Brasil. Os micos consumiram frutos de 57 espécies de pelo menos 17 famílias. Eles ingeriram sementes de 39 espécies, e 23 destas foram colocadas para germinar no laboratório e/ou no campo. L. rosalia é um dispersor de sementes legítimo porque sementes de todas as espécies testadas germinaram após a ingestão, mesmo que em baixas porcentagens. Esses primatas não apresentam um efeito consistente na germinação final de sementes, porque beneficiam algumas espécies enquanto prejudicam outras. Sementes predadas ou digeridas foram procuradas nas fezes.
\end{abstract}

Palavras-chave: Mata Atlântica, mico-leão-dourado, Leontopithecus rosalia, dispersão de sementes, germinação de sementes.

\section{Introduction}

The golden lion tamarin (Leontopithecus rosalia) is an endemic primate of the Atlantic Forest and feeds on a variety of insects, small vertebrates and fruits (Kierulff et al., 2002; Kleiman et al., 1988). The species is at risk of extinction and, according to IUCN (2004), its status has changed from "critically endangered" to "endangered". Nowadays, the wild population is restricted to six municipalities in the state of Rio de Janeiro (Kierulff et al., 2003).

The lowland Atlantic forest of the state of Rio de Janeiro is one of the most endangered biomes in the world (Kitching, 2000; Myers et al., 2000; Reid, 1998). The fragmentation and deforestation of forests where tamarins occur are the main factors affecting the species (Kierulff et al., 2002), and the remaining populations are small sized and isolated in fragments of forests (Kierulff et al., 2003).

Seed dispersal is fundamental to the recuperation of biodiversity due to the improvement in the restoration of degraded areas (Wunderle-Jr, 1997; Trakhtenbrot et al., 2005). In most tropical forests, at least half of the tree species produce fleshy fruits adapted for bird or mammal consumption (Howe and Smallwood, 1982; Motta-Junior and Lombardi, 2002). Frugivorous activity can influence food availability for other consumers, the germination and survival of seeds, and the recruitment of seedlings 
for the next generation of trees in the forest (Fuentes, 2000; Lambert and Garber, 1998).

Frugivores may be legitimate and/or efficient seed dispersers (Bustamante et al., 1992; Herrera, 1989; Schupp, 1993; Jordano and Schupp, 2000). A disperser is considered legitimate when the seeds found in the feces pass intact through the animal gut. The dispersers can act in the two components of germination: in the percentage of seed germination after gut passage, and in the time that seeds take to germinate (Traveset, 1998).

Primates represent a significant portion of frugivorous vertebrate biomass in tropical communities (Garber and Lambert, 1998; Terborgh, 1983; 1986). Many studies show their importance as dispersers, partly due to the many ingested seeds that retain their viability after defecation (Chapman, 1989; Estrada et al., 1984; Estrada and CoatesEstrada, 1991; Figueiredo, 1993; Howe, 1980; Lieberman et al., 1979; McConkey, 2000; Nunes, 1995; Passos, 1997; Sanches and Pedroni, 1994; Zhang and Wang, 1995). They affect the structure and composition of the plants with which they interact (Chapman, 1995), and may play an important role in the regeneration of the fragmented areas where most of them occur (Oliveira and Ferrari, 2000).

Dispersers ingest or transport unharmed seeds, while predators have morphological adaptations to destroy them (Norconk et al., 1998). Environmental conditions, food availability and fruit production lead a vertebrate to act as a predator or dispersal agent (Garber and Lambert, 1998; Gautier-Hion et al., 1993; Janzen, 1971; Kaplin and Moermond, 1998).

The role of primates as seed dispersers is not adequately understood. A lack of information exists for several species due to variations in their anatomy, ecology, techniques of fruit exploitation, food passage time and dispersal (Garber and Lambert, 1998). A previous study with $L$. chrysopygus (black-lion-tamarin) shows that the passage of seeds through the gut improves germination for many species (Passos, 1997). The only information about seed dispersal by golden lion tamarins is from Coimbra-Filho (1969), who mentions L. rosalia as a possible disperser agent due to the viability of ingested Tapirira guianensis seeds. This is the first study to determine the role of golden lion tamarins in seed dispersal in the Atlantic Forest.

The aim of this study was to evaluate the influence of the golden lion tamarin (Leontopithecus rosalia) as a seed disperser in a forest fragment of the Atlantic forest in south-east Brazil, assessing the effects of gut passage on percentage and speed (rate) of seed germination, and whether or not they act as seed predators.

The Golden Lion Tamarin Association is establishing forest corridors between isolated forest fragments on private farms. The corridors will represent additional forest area for the species, increasing the genetic flow among populations. The understanding of the role of golden lion tamarins as seed dispersers may help in the selection of plant species used in future corridors (Lapenta, 2002), and to improve data to implement future seed banks and seedling nurseries.

\section{Material and Methods}

This study was carried out at the União Biological Reserve (22 $27^{\prime} 36^{\prime \prime} \mathrm{S}$, and $\left.42^{\circ} 02^{\prime} 15^{\prime \prime} \mathrm{W}\right)$, located in Rio das Ostras and Casimiro de Abreu, Rio de Janeiro, Brazil. The area is administered by IBAMA (The Brazilian Environmental Institute) and has 3,121.2 ha with approximately 2,400 ha of lowland tropical forest, divided into two sections by a Federal Highway BR 101 (500 ha on the south and 1,900 ha on the north). The area shows three types of vegetation based on topographic and drainage systems: swamp forest, lowland forest and hills (Kierulff et al., 2003). The climate in the region is hot and humid with a defined seasonality (Kleiman et al., 1988). The annual rainfall was $1,549.3 \mathrm{~mm}$ during the study period, with temperatures averaging $24.2^{\circ} \mathrm{C}$. The dry season occurs from April to September (494.8 mm), and the wet season from October to March $(1,054.5 \mathrm{~mm})$.

Two groups of golden lion tamarins (LB and SJ2) were followed monthly using telemetry equipment (Telonics TR-4 receptor), from December 1998 to December 2000, on a total of 871.9 hours. The groups were followed from the time they left their sleeping sites until the end of the day to collect diet and defecation data. During the study period, the LB group size ranged from three to six individuals, and the SJ2 group size varied from six to 12 individuals. The data from the two groups were pooled together for analysis.

Each fruiting tree visited by tamarins was marked with numbered flags, and the habitat and the position (" $x$ " and " $y$ " coordinates) were noted and plotted on a map of the area. The portion of fruits consumed and the fate of the seeds spat out, ingested or preyed upon) were noted. Samples of fruits in the same degree of ripeness such as the fruits ingested by the lion tamarins were collected for germination experiments under the trees or directly from the branches. All the feces with ingested seeds were collected immediately after being defecated by the tamarins. The feces were numbered and plotted on the map of the area.

The golden lion tamarin was considered a seed predator for the species whose seeds were physically damaged or digested. The behavior of the individuals was continually observed during the ingestion of each fruit species. Digested and damaged seeds were searched for and quantified in the feces.

In addition to evaluating the legitimacy of the golden lion tamarins as seed dispersers, the study also assessed the delay in germination and the percentage of seeds germinated. The seed germination tests used the species available and consumed by the golden lion tamarins, with a sufficient number of control seeds (from fruits) and treated seeds (from feces). Tests with seeds from 23 species (10 to 420 seeds) were conducted in the laboratory under diffuse light and room temperature. Seeds were extracted with pincers, washed in running water and put to germinate on filter paper, in Petri dishes, with an equal number in both treatments (using control seeds from at least five fruits in each experiment). The 
percentage of germination and the germination rate or speed (sensu Traveset, 1998) were checked every two days (Figueiredo, 1993), until the end of germination or obvious death of the seeds.

Seeds from feces and fruits of nine species were planted to germinate under natural conditions in the forest (local light, temperature and humidity), in the location where they were defecated. The seeds were put to germinate in transparent plastic pots (control pots sideby-side with treatments pots), with local soil, covered to protect against secondary dispersers and predators, but with small orifices in the lid and on the bottom to permit the flux of water and air.

For some species, more than one germination test were conducted because the tamarins had eaten the same fruit species in consecutive months. A minimum of five dishes (replicates) was used, with eight to 20 seeds per dish. For the species with less than 40 seeds per treatment, replicates were not used, and the seeds were placed in the same dish. The statistical comparison of the germination percentage was done with the Chi-square test (using Yates correction for $n<200$ and degree of freedom = 1). In the tests with replicates, the one-way Analysis of Variance was used (using the arcsine transformation, to normalize the data) (Traveset and Wilson, 1997; Yagihashi et al., 1999; Zar, 1984). To compare the differences in germination pattern between the treatments over time, the Kolmogorov-Smirnov test was used (Bizerril and Raw, 1998; Lieberman and Lieberman, 1986; McConkey, 2000; Siegel and Castellan, 1988) and, for the species with replicates, the Analysis of Variance with repeated measurements was used (using the arcsine transformation, to normalize the data) (Traveset and Wilson, 1997; Yagihashi et al., 1999). The ANOVA analysis was done with STATISTICA 5.0 for Windows.

\section{Results and Discussion}

\subsection{Fruit and feces collection}

During the study, both tamarin groups consumed 57 fruit species, swallowing the seeds from 39 of them. The majority of fruits were yellow, (Lapenta, 2002; Lapenta et al., 2003) with distinct sizes (Table 1). The seeds deposited by the tamarins are not enveloped in much organic material. The feces are not compact but have little texture.

\subsection{Germination tests}

The results show that golden lion tamarins increased the final percentage of seed germination in seven of the

Table 1. Size of fruits and seeds eaten by golden lion tamarins.

\begin{tabular}{lccc}
\hline & & \multicolumn{2}{c}{ Means (mm) } \\
\cline { 3 - 4 } & & Width & Length \\
\hline Fruits & - & $15.6 \pm 8.4$ & $18.6 \pm 11.1$ \\
Seeds & Swallowed & $7.4 \pm 2.8$ & $11.3 \pm 5.0$ \\
& Dropped & $8.1 \pm 3.4$ & $13.9 \pm 6.0$ \\
\hline
\end{tabular}

23 species tested in the lab $(30.4 \%)$ and decreased it in three species $(13 \%)$. The germination did not differ significantly in two treatments for eleven species (47.8\%) (Table 2). For the seeds tested in the field (Table 3), the results showed that the germination did not differ in both treatments for seven of the eight species tested (87.5\%), and was not conclusive for one species $(12.5 \%)$. In the field, the humidity, light and water may have influenced the germination, however the number of seeds used in the field was small in comparison with the tests conducted in the laboratory. In total, 48 tests were conducted, and the final germination percentage was improved after tamarin gut passage in $25 \%$ of the tests, and decreased in $12.5 \%$ (Tables 1 and 2). L. rosalia may be considered to be a legitimate disperser agent (sensu Reid, 1989) for the most of the species tested in the lab and in the field, because the seeds germinated, albeit some in small percentages (range of 1\%-100\%). The species Rollinia dolabripetala (Annonaceae) and Passiflora rhamnifolia (Passifloraceae) were the only ones that did not germinate after ingestion, but the same occurred with control seeds. Other abiotic factors, such as temperature, light, moisture or nutrients, can explain seed dormancy (Kageyama and Piña-Rodrigues, 1993).

The seeds of Inga thibaudiana and I. edulis (Fabaceae) tested in lab or in the field showed no differences in germination percentage between treatments. In spite of the small number of seeds used in the tests, the golden lion tamarin cannot be considered a good disperser for these species, because most of seeds consumed were not ingested, being discarded under the parental tree. Future studies with a great number of seeds are necessary to test if the percentage and/or rate of germination are improved just with the removal of the seeds from inside of the pod.

The inhibition of seed germination in some species may occur when they are ingested before they are completely ripe (Traveset, 1998). This could be the reason for the low percentage of germination in the tested seeds of Pourouma guianensis.

The velocity of seed germination (Table 2) was significantly shorter after passing through the gut of the tamarins in eight of 21 species tested in the lab (38.1\%), with no differences in germination velocity in seven of them $(33.3 \%)$. Three species had a low germination velocity for defecated seeds $(14.3 \%)$, and the results were not conclusive for another two species $(9.5 \%)$. For seeds tested in the field (Table 3), the velocity of germination after passing through the gut of the tamarin was not significantly different in five species $(62.5 \%)$, decreased in one $(12.5 \%)$, and increased in another $(12.5 \%)$. For the last species, the results of three tests were inconclusive. Nevertheless, it must be pointed out that, for seeds put in the field, the interval of germination checking was greater than in the lab. In 42 tests of germination velocity, the passage through the tamarin gut enhanced the germination velocity in $28.6 \%$ of the tests, and decreased it in $14.3 \%$. Traveset (1998), in a compilation of studies 
Table 2. Germination tests for defecated and control seeds, with the percentage of germinated seeds and germination velocity.

\begin{tabular}{|c|c|c|c|c|c|c|}
\hline \multirow[t]{3}{*}{ Family } & \multirow{3}{*}{ Species } & \multicolumn{5}{|c|}{ (\%) of seeds germinated } \\
\hline & & \multirow{2}{*}{$\mathbf{N}$} & \multirow{2}{*}{$\frac{\text { Fecal }}{(\%)}$} & \multirow{2}{*}{$\frac{\text { Control }}{(\%)}$} & \multirow[t]{2}{*}{$\chi^{2} / \mathbf{F}$} & \multirow[t]{2}{*}{$\mathbf{P}$} \\
\hline & & & & & & \\
\hline \multirow[t]{2}{*}{ ANACARDIACEAE } & Tapirira guianensis & 17 & 100 & 11.8 & $\chi^{2}=23.4$ & $<0.01+$ \\
\hline & T. guianensis & 48 & 85.4 & 45.8 & $\mathrm{~F}=14.3$ & $<0.05+$ \\
\hline ANNONACEAE & Rollinia dolabripetala & 30 & 0 & 0 & - & - \\
\hline \multirow[t]{4}{*}{ CECROPIACEAE } & Cecropia hololeuca & 360 & 80.5 & 57.2 & $\mathrm{~F}=14.2$ & $0.001+$ \\
\hline & C. pachystachya & 420 & 30 & 12.4 & $F=20.3$ & $0.000+$ \\
\hline & Pourouma guianensis & 58 & 12.1 & 0 & - & + \\
\hline & P. guianensis & 23 & 17.4 & 0 & - & + \\
\hline EUPHORBIACEAE & Unknown 1 & 180 & 94.4 & 82.2 & $\mathrm{~F}=9.2$ & $<0.01+$ \\
\hline \multirow[t]{2}{*}{ FABACEAE } & Inga thibaudiana & 27 & 85 & 100 & $\chi^{2}=2.4$ & ns \\
\hline & I. edulis & 18 & 100 & 100 & - & ns \\
\hline \multirow[t]{8}{*}{ MELASTOMATACEAE } & Miconia hypoleuca & 270 & 35 & 92 & $F=69.8$ & $<0.001-$ \\
\hline & M. hypoleuca & 160 & 86 & 96 & $\mathrm{~F}=13.1$ & $<0.01-$ \\
\hline & M. latecrenata & 385 & 30.4 & 18.4 & $\mathrm{~F}=5.8$ & $<0.05+$ \\
\hline & M. latecrenata & 180 & 51.7 & 42.2 & $F=5.7$ & $<0.05+$ \\
\hline & M. latecrenata & 120 & 56 & 52 & $\mathrm{~F}=0.4$ & ns \\
\hline & M. cf. lepidota & 300 & 35.7 & 83.6 & $F=38.6$ & $0.00-$ \\
\hline & M. cf. lepidota & 140 & 1.4 & 46.4 & $F=46.8$ & $0.001-$ \\
\hline & Henriettea saldanhei & 330 & 9.7 & 81.8 & $\mathrm{~F}=1.7$ & $0.001-$ \\
\hline \multirow[t]{5}{*}{ MYRTACEAE } & Calyptranthes lucida & 60 & 96.7 & 100 & $\chi^{2}=0.5$ & ns \\
\hline & Myrcia sp.1 & 50 & 98 & 90 & $\mathrm{~F}=2.2$ & ns \\
\hline & Marlierea sp.1 & 10 & 100 & 90 & $\chi^{2}=0$ & ns \\
\hline & Myrtaceae sp.1 & 19 & 94.7 & 100 & $\chi^{2}=0$ & ns \\
\hline & $\begin{array}{l}\text { Campomanesia } \\
\text { eugenioides }\end{array}$ & 14 & 100 & 21.4 & $\chi^{2}=15.0$ & $0.001+$ \\
\hline \multirow[t]{2}{*}{ PASSIFLORACEAE } & Passiflora rhamnifolia & 160 & 0 & 0 & - & - \\
\hline & Passiflora rhamnifolia & 50 & 0 & 0 & - & - \\
\hline \multirow[t]{4}{*}{ RUBIACEAE } & Tocoyena brasiliensis & 26 & 84.6 & 80.8 & $\chi^{2}=0$ & ns \\
\hline & T. brasiliensis & 26 & 84.6 & 96.1 & $\chi^{2}=0.9$ & ns \\
\hline & Randia sp.1 & 40 & 95 & 90 & $\chi^{2}=0.2$ & ns \\
\hline & Posoqueria latifolia & 12 & 91.7 & 66.7 & $\chi^{2}=1.0$ & ns \\
\hline \multirow[t]{6}{*}{ SAPOTACEAE } & Sarcaulus brasiliensis & 20 & 80 & 90 & $\chi^{2}=0.3$ & ns \\
\hline & S. brasiliensis & 36 & 83 & 14 & $\chi^{2}=32.0$ & $0.001+$ \\
\hline & S. brasiliensis & 16 & 69 & 62 & $\chi^{2}=0$ & ns \\
\hline & S. brasiliensis & 30 & 40 & 60 & $\chi^{2}=2.4$ & ns \\
\hline & S. brasiliensis & 11 & 45 & 36 & $\chi^{2}=0$ & $\mathrm{~ns}$ \\
\hline & $\begin{array}{l}\text { Micropholis } \\
\text { gardneriana }\end{array}$ & 125 & 86.4 & 68 & $\mathrm{~F}=2.34$ & ns \\
\hline
\end{tabular}

$\%$ Fecal $=\%$ of germinated seeds from feces; $\%$ Control $=\%$ of germinated seeds from fruits; $(+)=$ enhancement of $\%$ or velocity of germination by the tamarins; $(-)=$ decrease of $\%$ or velocity of germination by the tamarins; $1^{\text {st }}=$ number of days for first seed to germinate; Final = germination delay; and ns = non significant tests $(p>0,05)$. 
Days to germination

\begin{tabular}{|c|c|c|c|c|c|c|c|}
\hline \multicolumn{2}{|c|}{ Fecal } & \multicolumn{2}{|c|}{ Control } & \multirow[t]{2}{*}{$\mathrm{D} / \mathrm{F}$} & \multirow[t]{2}{*}{$\mathbf{p}$} & \multirow{2}{*}{$\begin{array}{c}\text { Time } x \\
\text { Treatments }\end{array}$} & \multirow[t]{2}{*}{$\mathbf{p}$} \\
\hline $1^{\text {st }}$ & Final & $1^{\text {st }}$ & Final & & & & \\
\hline 2 & 6 & 7 & 7 & $\mathrm{D}=0.6$ & ns & - & - \\
\hline 3 & 7 & 3 & 7 & $F 1,10=28.05$ & $<0.001$ & $\mathrm{~F} 5,50=3.13$ & $0.01+$ \\
\hline 0 & 0 & 0 & 0 & - & - & - & - \\
\hline 9 & 54 & 9 & 82 & $\mathrm{~F} 1,16=4.75$ & $<0.05$ & $\mathrm{~F} 20,320=59.6$ & $<0.001-$ \\
\hline 10 & 134 & 10 & 88 & $F 1,26=13.75$ & 0.001 & $\mathrm{~F} 19,494=3.7$ & $<0.001+$ \\
\hline 71 & 155 & 0 & 0 & - & - & - & - \\
\hline 117 & 22 & 0 & 0 & - & - & - & - \\
\hline 1 & 13 & 1 & 13 & $\mathrm{~F} 1,16=15.13$ & $0.001+$ & $\mathrm{F} 3,48=0.03$ & ns \\
\hline 2 & 2 & 2 & 2 & - & ns & - & - \\
\hline 5 & 2 & 7 & 2 & - & ns & - & - \\
\hline 30 & 93 & 18 & 37 & $\mathrm{~F} 1,16=220$ & $<0.001-$ & $\mathrm{F} 28,448=36.1$ & $<0.001-$ \\
\hline 21 & 84 & 25 & 129 & $\mathrm{~F} 1,14=0.17$ & ns & $\mathrm{F} 18,252=7.8$ & $<0.001+$ \\
\hline 19 & 114 & 19 & 114 & $\mathrm{~F} 1,12=3.18$ & ns & $\mathrm{F} 18,216=1.9$ & $<0.05+$ \\
\hline 23 & 171 & 17 & 117 & $\mathrm{~F} 1,10=1.63$ & ns & $\mathrm{F} 21,210=2.9$ & $<0.001+$ \\
\hline 19 & 171 & 13 & 171 & $\mathrm{~F} 1,10=2.25$ & ns & $\mathrm{F} 14,140=9.8$ & $<0.001-$ \\
\hline 21 & 81 & 17 & 106 & $\mathrm{~F} 1,18=37.1$ & $<0.001-$ & $\mathrm{F} 30,540=5.9$ & $<0.001-$ \\
\hline 36 & 61 & 21 & 77 & $\mathrm{~F} 1,12=139.3$ & $<0.001$ & $\mathrm{~F} 15,180=18.4$ & $<0.001-$ \\
\hline 25 & 35 & 22 & 133 & $\mathrm{~F} 1,20=123.3$ & $<0.001-$ & $\mathrm{F} 23,460=28.5$ & $<0.001-$ \\
\hline 4 & 28 & 4 & 14 & $\mathrm{D}=0.2$ & $<0.05+$ & - & - \\
\hline 5 & 5 & 5 & 20 & $\mathrm{~F} 1,8=7.28$ & $<0.05$ & $\mathrm{~F} 5,40=0.33$ & ns \\
\hline 4 & 4 & 8 & 7 & $\mathrm{D}=1$ & $<0.01+$ & - & - \\
\hline 4 & 62 & 4 & 22 & $\mathrm{D}=0.4$ & ns & - & - \\
\hline 3 & 9 & 12 & 19 & $\mathrm{D}=0.9$ & $<0.05+$ & - & - \\
\hline 0 & 0 & 0 & 0 & - & - & - & - \\
\hline 0 & 0 & 0 & 0 & - & - & - & - \\
\hline 25 & 63 & 42 & 81 & $\mathrm{D}=0.5$ & $<0.01+$ & - & - \\
\hline 30 & 54 & 35 & 71 & $\mathrm{D}=0.5$ & $<0.01+$ & - & - \\
\hline 20 & 49 & 27 & 31 & $\mathrm{D}=0.3$ & $<0.05+$ & - & - \\
\hline 21 & 7 & 21 & 16 & $\mathrm{D}=0.35$ & $\mathrm{~ns}$ & - & - \\
\hline 25 & 182 & 25 & 135 & $\mathrm{D}=0.4$ & ns & - & - \\
\hline 21 & 81 & 28 & 72 & $\mathrm{D}=0.5$ & ns & - & - \\
\hline 28 & 54 & 28 & 96 & $\mathrm{D}=0.3$ & ns & - & - \\
\hline 16 & 156 & 7 & 28 & $\mathrm{D}=0.2$ & ns & - & - \\
\hline 21 & 54 & 21 & 54 & $\mathrm{D}=0.5$ & ns & - & - \\
\hline 18 & 19 & 18 & 35 & $\mathrm{~F} 1,8=4.54$ & ns & $\mathrm{F} 13,104=3.1$ & $<0.001+$ \\
\hline
\end{tabular}




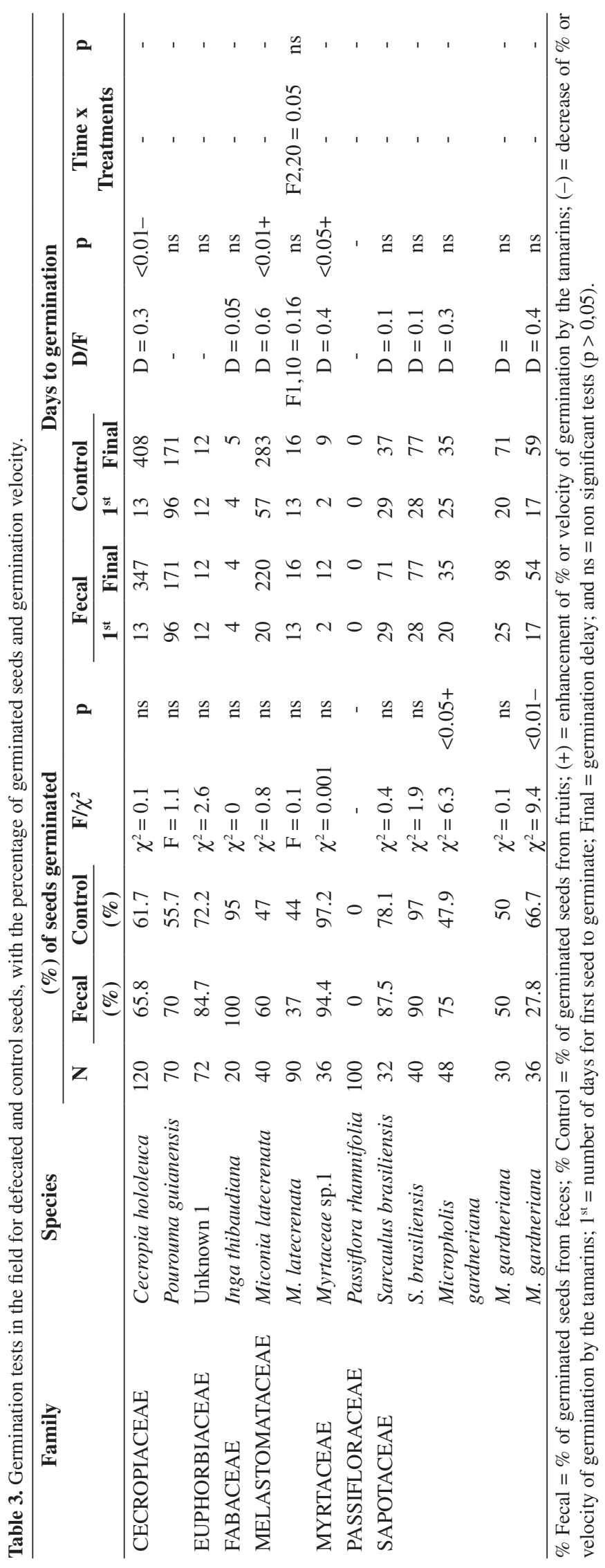


about seed dispersal, concluded that, unlike birds, primates do not generally interfere in the velocity (speed) of seed germination. The advantage of quick germination differs with the species, depending on the type of seed dormancy and ecological conditions of the habitat. The species that have no dormancy benefit more from fast germination than those with dormancy (Traveset and Verdú, 2002).

A given frugivorous species could have different effects on seed germination, depending on intrinsic characteristics of the plants eaten. Besides this, the same plant species can respond differently to the same frugivore depending on environmental conditions, plant population and/or seed age. Many factors may affect the results, such as the period of fruit collection, ripeness of ingested seeds, adequacy of seed deposition, seed size, and others (e.g. Chacon et al., 1998; Traveset, 1998; Jordano and Schupp, 2000; Traveset and Verdú, 2002; Wehncke et al., 2004).

In general, the primates do not show a consistent effect on seed germination, because they benefit some species and damage the percentage and/or germination velocity of others (Figueiredo, 1993; Lieberman et al., 1979; McConkey, 2000; Wehncke and Dalling, 2005; this study). If seed passage through the animal's gut does not alter the germination, the species acts only as a seed disseminator, moving the seeds from the parental plant. In fact, the seed treatment by the disperser is not so important, because they can deposit the seeds in suitable sites. Some studies consider that the main advantage of seed dispersal by animals to be the transport of seeds away from parental trees to places that are proper for germination (Traveset and Wilson, 1997). Other aspects like retention time, dispersal distance, seed predation and seedling recruitment are important to consider if the species is an efficient disperser or not (Stevenson, 2000; Wehncke et al., 2004; Wehncke and Dalling, 2005; Lapenta and Procópio-de-Oliveira, submitted).

\subsection{Seed predation}

Food availability can affect the role of a vertebrate as a predator or a dispersal agent (Gautier-Hion et al., 1993; Janzen, 1971). Some studies confirm that single species of vertebrates can have a large effect on the rate of seed mortality of a plant species, as a consequence of direct predation or inadequate dispersal (Peres, 1991). In this study, L. rosalia was not seen eating the content of seeds from any species, and digested seeds were not found in the feces. Nevertheless, during the handling of fruits, some seeds of Leguminous (Inga spp.) that were not ingested were slightly damaged, and could have lost the germination viability. For Inga thibaudiana, 12 seeds were found with teeth marks, spat out under the parental trees, and from 59 feces collected of that species only one had one damaged seed. For Inga edulis, only one seed spat out by tamarins was damaged, and in 24 feces collected for this species, not one had damaged seeds. Due to the small number of seeds collected, it was not possible to conduct the germination tests to verify their viability, but the number of preyed-upon seeds can be considered very low. From about 543 feces collected from the main 11 seed species consumed, only one feces of Inga thibaudiana was found with only one damaged seed.

Only Sarcaulus brasiliensis and Pourouma guianensis had some seeds ingested when unripe. The seeds of these species were also ingested when ripe, being capable of germination. In the future, studies should analyze the post-dispersal predation level for the seeds defecated by tamarins.

Acknowledgements - This study was supported by FAPESP (99/10860-8), USAID and WWF-Brasil (CSR186-2000), and PRONABIO/PROBIO/MMA/CNPq. We are grateful to the Departamento de Ecologia/IB of the Universidade de São Paulo (USP) and AMLD for the Institutional support, and to the Brazilian Environmental Institute (IBAMA) for the permission to work in the União Biological Reserve. We thank Karina Martins for the help with the germination tests and Roberto Shimizu for the help with the statistical analysis. Finally, we thank the Translocation Team: Vanessa Puerta Veruli, Sandro Vidal da Rocha, Nailton P. Azevedo, Hamilton Camargo-Filho, and all the people who collaborated with this work.

\section{References}

BIZERRIL, MXA. and RAW, A., 1998. Feeding behavior of bats and the dispersal of Piper arboreum seeds in Brazil. $J$. Trop. Ecol., vol. 14, p. 109-114

BUSTAMANTE, RO., SIMONETTI, JA. and MELLA, JE., 1992. Are foxes legitimate and efficiente seed dispersers? A field test. Acta Oecol., vol. 13, no. 2, p. 203-208.

CHACON, P., BUSTAMANTE, RO. and HENRIQUEZ, C., 1998. The effect of seed size on germination and seedling growth of Cryptocarya alba (Lauraceae) in Chile. Rev. Chilena de Hist. Nat., vol. 71, p. 189-197.

CHAPMAN, C., 1989. Primate Seed Dispersal: The Fate of Dispersed Seeds. Biotropica, vol. 21, no. 2, p. 148-154.

-, 1995. Primate Seed Dispersal: Coevolution and Conservation Implications. Evol. Anthropol., vol. 4, p. 74-82.

COIMBRA-FILHO, AF., 1969. Mico-Leão, Leontideus rosalia (Linnaeus, 1766), situação atual da espécie no Brasil (Callitrichidae - Primates). Annais Acad. Brasil. Ciência, vol. 41, suppl., p. 29-52.

ESTRADA, A., COATES-ESTRADA, R., VASQUEZYANES, C. and OROZCO-SEGOVIA, A., 1984. Comparison of Frugivory by Howling Monkeys (Alouatta palliata) and Bats (Artibeus jamaicensis) in the Tropical Rain Forest of Los Tuxtlas, Mexico. Am. J. Primatol., vol. 7, p. 3-13.

ESTRADA, A. and COATES-ESTRADA, R., 1991. Howler monkeys (Alouatta palliata), dung beetles (Scarabaeidae) and seed dispersal: ecological interactions in the tropical rain forest of Los Tuxtlas, Mexico. J. Trop. Ecol., vol. 7, p. 459-474.

FIGUEIREDO, RA., 1993. Ingestion of Ficus enormis by howler monkeys (Alouatta fusca) in Brazil: effects on seed germination. J. Trop. Ecol., vol. 9, p. 541-543.

FUENTES, M., 2000. Frugivory, seed dispersal and plant community ecology. TREE, vol. 15 , no. 12, p. 487-488. 
GARBER, PA. and LAMBERT, JE., 1998. Introduction to Primate Seed Dispersal. Primate as Seed Dispersers: Ecological Processes and Directions for Future Research. Am. J. Primatol., vol. 45 , no. 1 , p. $3-8$.

GAUTIER-HION, A., GAUTIER, JP. and MAISELS, F., 1993. Seed dispersal versus seed predation: an inter-site comparison of two related African monkeys. Vegetatio, vol. 107-108, p. 237-244.

HERRERA, CM., 1989. Frugivory and seed dispersal by carnivorous mammals, and associated fruit characteristics in undisturbed Mediterranean habitats. Oikos, vol. 55, no. 2, p. 250-262.

HOWE, HF., 1980. Monkey dispersal and waste of a neotropical fruit. Ecology, vol. 61, no. 4, p. 944-959.

HOWE, HF. and SMALLWOOD, J., 1982. Ecology of seed dispersal. Ann. Rev. Ecol. Syst., vol. 13, p. 201-228.

IUCN (WORLD CONSERVATION UNION), 2004. IUCN Red List of Threatened Species. Gland, Suíça: IUCN - World Conservation Union.

JANZEN, DH., 1971. Seed predation by animals. Ann. Rev. Ecol. Syst., vol. 2, p. 465-492.

JORDANO, P. and SCHUPP, EW., 2000. Seed disperser effectiveness: The quantity component and patterns of seed rain for Prunus mahaleb. Ecol. Monogr., vol. 70, no. 4, p. 591-615.

KAGEYAMA, PY. and PIÑA-RODRIGUES, FCM., 1993. Fatores que Afetam a Produção de Sementes. In AGUIAR, IB., PIÑA-RODRIGUES, FCM. and FIGLIOLIA, MB. (eds.). Sementes Florestais Tropicais. Brasília: Associação Brasileira de Tecnologia de Sementes.

KAPLIN, B. and MOERMOND, TC., 1998. Variation in Seed Handling by Two Species of Forest Monkeys in Rwanda. Am. J. Primatol., vol. 45, no. 1, p. 83-101.

KIERULFF, MCM., RABOY, BE., PROCÓPIO-DEOLIVEIRA, P., MILLER, K., PASSOS, FC. and PRADO, F., 2002. Behavioral Ecology of Lion Tamarins. In KLEIMAN, DG. and RYLANDS, AB. (eds.). Lion Tamarins Biology and Conservation, Smithsonian Institution Press, 422 p.

KIERULFF, MCM., RAMBALDI, DM. and KLEIMAN, DG., 2003. Past, Present, and Future of the Golden Lion Tamarin and its Habitat. In: GALINDO - LEAL and CÂMARA, IG. (eds.). The Atlantic Forest of South America: Biodiversity Status, Threats, and Outlook, C. Washington, DC: Island Press. 488 p.

KITCHING, R., 2000. Biodiversity, hotspots and defiance. TREE, vol. 15, p. 484-485.

KLEIMAN, D., HOAGE, RJ. and GREEN, KM., 1988. The lion tamarins, genus Leontopithecus. In MITTERMEIER, RA., RYLANDS, AB., COIMBRA-FILHO, AF. and FONSECA, GAB. (eds.). Ecology and Behaviour of Neotropical Primates-II. Washington, D.C: World Wildlife Fund, 610 p.

LAMBERT, JE. and GARBER, PA., 1998. Evolutionary and Ecological implications of primate seed dispersal. Am. J. Primatol., vol. 45, no. 1, p. 9-28.

LAPENTA, MJ. 2002. The golden lion tamarin (Leontopithecus rosalia) as a seed dispersor in the União Biological Reserve/ IBAMA, Rio das Ostras, RJ. (Master Thesis) - University of São Paulo, São Paulo, 96 p.
LAPENTA, MJ., PROCÓPIO-DE-OLIVEIRA, P., KIERULFF, MCM. and MOTTA-JUNIOR, JC., 2003. Fruit exploitation by Golden Lion Tamarins (Leontopithecus rosalia) in the Uniao Biological Reserve, Rio das Ostas, RJ, Bazil. Mammalia, vol. 67 , no. 1, p. 41-46.

LIEBERMAN, D., HALL, JB., SWAINE, MD. and LIEBERMAN, M., 1979. Seed Dispersal by Baboons in the Shai Hills, Ghana. Ecology, vol. 60, no. 1, p. 65-75.

LIEBERMAN, M. and LIEBERMAN, D., 1986. An experimental study of seed ingestion and germination in a plantanimal assemblage in Ghana. J. Trop. Ecol., vol. 2, p. 113-126.

MCCONKEY, KR., 2000. Primary Seed Shadow Generated by Gibbons in the Rain Forest of Barito Ulu, Central Borneo. Am. J. Primatol., vol. 52, no. 1, p. 13-29.

MOTTA-JUNIOR, JC. and LOMBARDI, JA., 2002. Ocorrência de zoocoria em florestas-de-galeria no Complexo do Cerrado, Brasil. Biotemas, vol. 15, no. 1, p. 59-81.

MYERS, N., MITTERMEIER, RA., MITTERMEIER, CG., FONSECA, GAB. and KENT, J., 2000. Biodiversity hotspots for conservation priorities. Nature, vol. 403, p. 853-858.

NORCONK, MA., GRAFTON, BW. and CONKLINBRITTAIN, NL., 1998. Seed Dispersal by Neotropical Seed Predators. Am. J. Primatol., vol. 45, no. 1, p. 103-126.

NUNES, A., 1995. Um teste de germinação em sementes dispersas por macacos-aranha em Maracá, Roraima; Brasil. Studies Neotrop. Fauna Environm., vol. 30, no. 1, p. 31-36.

OLIVEIRA, AC. and FERRARI, SF., 2000. Seed dispersal by black-handed tamarins, Saguinus midas niger (Callitrichinae, Primates): implications for the regeneration of degraded forest habitats in eastern Amazonia. J. Trop. Ecol., vol. 16, p. 709-716.

PASSOS, FC., 1997. Seed dispersal by black lion tamarin, Leontopithecus chrysopygus (Primates, Callitrichidae), in southeastern Brazil. Mammalia, vol. 61, no. 1, p. 109-111.

PERES, CA., 1991. Seed Predation of Cariniana micrantha (Lecythidaceae) by Brown Capuchin Monkey in Central Amazonia. Biotropica, vol. 23, no. 3, p. 262-270.

REID, N., 1989. Dispersal of Mistletoes by Honeyeaters and Flowerpeckers: Components of Seed Dispersal Quality. Ecology, vol. 70, no. 1, p. 137-145.

REID, WV., 1998. Hotspots Biodiversity. TREE, vol. 13, no. 7, p. $275-280$.

SANCHES, M. and PEDRONI, F., 1994. Dispersão de Sementes de Pereskia aculeata Miller (Cactaceae) no Sudeste do Brasil. Resumos do 20 Congresso Brasileiro de Zoologia, Universidade Federal do Rio de Janeiro, RJ.

SCHUPP, EW., 1993. Quantity, quality and the effectiveness of seed dispersal. Vegetatio, vol. 107/108, p. 15-29.

SIEGEL, S. and CASTELLAN-JUNIOR, NJ., 1988. Nonparametric Statistics for the Behavioral Sciences. $2^{\text {nd }} e d$. Singapore: McGraw-Hill Book Company, 399 p.

STEVENSON, PR., 2000. Seed dispersal by woolly monkeys (Lagothrix lagothricha) at Tinigua National park, Colombia: dispersal distance, germination rates, and dispersal quantity. Am. J. Primatol., vol. 50, no. 4, p. 275-289.

TERBORGH, J., 1983. Five New World Primates. Princeton, N.J: Princeton University Press, 260 p. 
-, 1986. Keystone Plant Resources in the Tropical Forest. In: SOULÉ, M. (ed.). Conservation Biology: the Science of Scarcity and Diversity. Sunderland Mass: Sinauer Associates.

TRAKHTENBROT, A., NATHAN, R., PERRY, G. and RICHARDSON, DM., 2005. The importance of longdistance dispersal in biodiversity conservation. Diversity and Distributions, vol. 11, p. 173-181.

TRAVESET, A. and WILSON, MF., 1997. Effect of birds and bears on seed germination of fleshy-fruited plants in temperate rainforest of southeast Alaska. Oikos, vol. 80, p. 89-95.

TRAVESET, A., 1998. Effect of seed passage through vertebrate frugivores'guts on germination: a review. Perspect. Plant Ecol., Evol. Syst., vol. 1, no. 2, p. 151-190.

TRAVESET, A. and VERDÚ, M., 2002. A Meta-analysis of the Effect of Gut Treatmens on Seed Germination. In LEVEY, DJ., SILVA, WR. and GALETTI, M. (eds.). Seed Dispersal and Frugivory: Ecology, Evolution and Conservation. Wallingford, UK: CABI Publishing, $544 \mathrm{p}$.

WEHNCKE, EV., VALDEZ, CN. and DOMINGUEZ, A., 2004. Seed dispersal and defecation patterns of Cebus capucinus and
Alouatta palliata: consequences for seed dispersal effectiveness. J. Trop. Ecol., vol. 20, p. 535-543.

WEHNCKE, EV. and DALLING, JW., 2005. Post-dispersal seed removal and germination selected tree species dispersed by Cebus capucinus on Barro Colorado Island, Panama. Biotropica, vol. 37, p. 73-80.

WUNDERLE-JR., JM., 1997. The role of animal seed dispersal in accelerating native forest regeneration on degraded tropical lands. Forestry Ecol. Managem., vol. 99, p. 223-235.

YAGIHASHI, T., HAYASHIDA, M. and TOSHIZUMI, M., 1999. Effects of bird ingestion on seed germination of two Prunus species with different fruit-ripening seasons. Ecol. Research, vol. 14, p. 71-76.

ZAR, JH., 1984. Biostatistical Analysis. 2 ed. New Jersey: Prentice-Hall, 718 p.

ZHANG, SY. and WANG, LX., 1995. Fruit consumption and seed dispersal of Ziziphus cinnamomum (Rhamnaceae) by two sympatric primates (Cebus apella and Ateles paniscus) in French Guiana. Biotropica, vol. 27, no. 3, p. 397-401. 